\title{
Landsat Computer-aided Analysis Techniques for Range Vegetation Mapping
}

\author{
JERROLD F. MCGRAW AND PAUL T. TUELLER
}

\begin{abstract}
Landsat computer-aided analysis techniques were used to map the sagebrush-grass vegetation of northern Nevada. A final Landsat digital classification resulted in 14 spectral classes representing 8 range plant communities. Classification accuracy for all sample plots was $86.4 \%$, with individual class accuracies ranging from 77.8 to $95.4 \%$. Classification methods included supervised, unsupervised, and guided clustering techniques using a maximum likelihood classifier.
\end{abstract}

Rangeland inventory techniques have been subject to question and controversy since the beginning of range management. The problems include cost, adequate trained manpower, the requirement to inventory vast areas and the obtaining of an adequate sample. Remote sensing techniques have often been suggested and promoted for doing basic range inventories. The repetitive availability, relatively low cost per unit area, and digitized format of the Landsat data make such information of potential interest to range managers. This study was designed to measure the success of Landsat computer-aided analysis techniques for range vegetation mapping in Northern Nevada.

Landsat digital data has seen only limited application on rangeland despite its potential for providing large quantities of vegetation mapping data at reasonable cost. Resolution limitations of the digital data (.42 ha or approximately 1.12 acres) along with complexity, diversity, and heterogeneity of range vegetation have tended to discourage its use.

Several researchers have evaluated the application of Landsat digital data for mapping range and arid land vegetation (Daus 1975, Maxwell 1976, Tueller et al. 1978, Everitt et al. 1979, Todd et al. 1980, Everitt et al. 1981). Maxwell (1976) inventoried vegetation types, range condition, and green biomass on grasslands in Colorado using a supervised classification technique. He concluded that Landsat was a very useful inventory tool on grasslands. Tueller et al. (1978) used Landsat digital data to map various arid land vegetation types in Australia.

Todd et al. (1980) classified various densities of pinyon-juniper on two different geologic types on the Shivwits Plateau in Arizona. Misclassification was the result of low canopy and high bare ground cover. Bonner and Morgart (1980) described an operational procedure for arid land vegetation inventories and the sampling units required for accurate classification. Recently Everitt et al. (1981) used digital pattern recognition techniques and a maximum likelihood ratio classification and found a highly significant correlation $\left(r^{2}=0.997\right)$ between air-photo and computer-estimated area of 5 land use categories for a June Landsat -2 scene. Condttions were not significant for an August overpass, suggesting the importance of selected dates to reduce misclassification.

Brush, mountain shrub/juniper, conifer, meadow, rock or bare ground and water were readily identified on rangeland near. Susanville, Calif. (Daus 1975). Classification problems occurred at ecotones and areas that contained mixes of vegetation types. Areas of low canopy cover were difficult to classify because of the spectral dominance of soil background. Sub-class classification problems

\footnotetext{
Authors are graduate research fellow and professor, Division of Renewable Natural Resources, University of Nevada Reno. This manuscript is published with approval of the Director, Nevada Agriculture Experiment Station as Journal Series No. 568.

Manuscript received June 21, 1982.
}

occurred in the big sagebrush communities with high proportions of bitterbrush, rabbitbrush, and other sagebrush species.

\section{Methods}

The objective of this study was to test the Landsat digital data for mapping range vegetation in sagebrush-grass areas of northern Nevada. The Saval Research Ranch, (located approximately 75 km north of Elko, Nev., on the east slope of the Independence Mountain Range), was selected as the study area. The vegetation is characteristic of the northern desert shrub type consisting mostly of deep-rooted big sagebrush (Artemisia tridentata tridentata) in the drainage bottoms and alluvial areas and a low-growing shallow-rooted sagebrush commonly referred to as early sagebrush (Artemisia longiloba) on arid claypan soils. Mountain big sagebrush (Artemisia tridentata vaseyana) and Wyoming big sagebrush (Artemisia tridentata wyomingensis) are found at higher and lower elevations respectively. There are 3 hay meadows on the ranch as well as riparian vegetation along drainages. A large crested wheatgrass (Agropyron desertorum) seeding is located on the southern portion of the ranch. All together the Saval Ranch test areas encompass approximately 15,619 ha.

A 13 June Landsat-2 scene was selected for this study because this time period is considered to be the peak growing season for most range plants on the study area.

PIXSYS' software, including algorithms for gray level mapping, supervised and unsupervised classification, density slicing, geometric correction, and a commonly used maximum likelihood classifier, was used in Landsat digital data analysis.

The spectral responses for Landsat digital data are best described as 4-band signatures that consist of the brightness values for the 4 multi-spectal channels ( 2 in the visible and 2 in the near infrared part of the spectrum). Differences in the reflectance on - brightness value for these 4 bands taken collectively describe the separability that then defines the range plant communities.

There are 3 basic methods used in creating spectral class statistics: supervised, unsupervised, and a mixed approach or guided clustering (Rohde 1978). In a supervised approach, training windows consisting of a group of pixels (picture elements) that are known to represent a range plant community from field observation are selected and related to ground data. Statistics describing these windows are generated by the computer (mean and standard deviation) and then extrapolated over the entire area being mapped and a classification and map are derived. This procedure has proved useful in agricultural areas and other landscapes where the mapping units are already known. However, for heterogeneous rangelands there are usually a significant number of pixels that are not classified because it is difficult to locate and jdentify homogeneous training sites for all existing range plant communities.

In an unsupervised approach, a clustering algorithm is used to group all pixels into clusters with similar spectral response. The spectral response limits of spectral clusters in PIXSYS can be controlled by setting maximum standard deviation, minimum distance between cluster centers, and a minimum number of pixels

'The PIXSYS soft ware package developed at Oregon State University was acquired for analysis of the Landsat digital data. 
Table 1. Single stage clustering parameters for determining sample size.

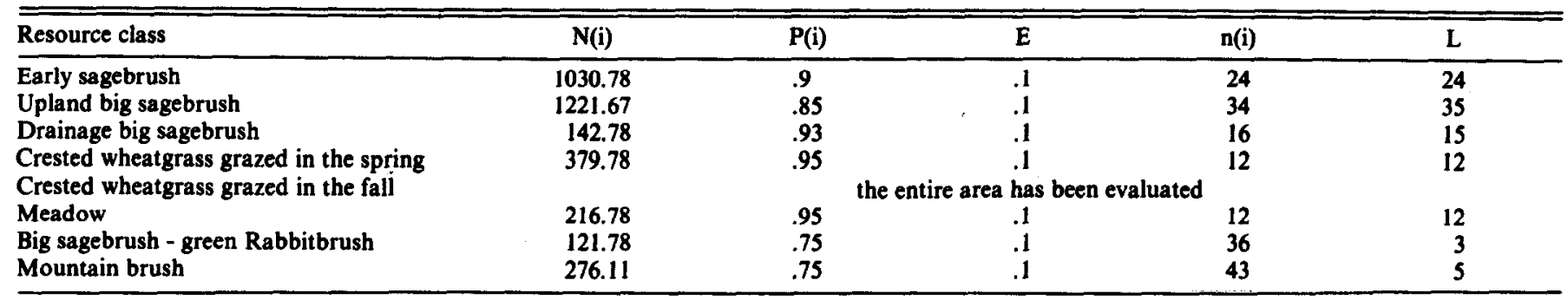

$N(i)$ is the total size of class $i / 9$

$P(i)$ is the estimated accuracy of class $i$.

$E$ is the estimated accuracy of class $i$.

$\mathbf{n}(i)$ is the number of clusters needed, (sample size).

$L$ is the actual number of clusters sampled, (actual sample size).

allowed in a cluster. This procedure classifies most pixels and can be interpreted and reinterpreted until the classification fits the range vegetation mosaic at an acceptable level as determined by ground sampling. It also eliminates the need for locating homogeneous training sites since the computer groups like pixels automatically.

In mixed or guided clustering approach a combination of the above 2 approaches is used. A training window, containing some general vegetation type as determined from field observation, is selected by the analyst to include subtle differences in vegetation patterns that are difficult to identify using either of the above 2 approaches alone. This allows the definition of unique 4-band signatures for homogeneous plant communities not readily defined in the unsupervised classification.

In this study a combination of all 3 of these methods was used to arrive at the final classification map. The supervised approach was used for the hay meadows and the unsupervised and guided clustering approaches were used on the various sagebrush communities.

\section{Accuracy Evaluation}

Ground data for evaluation plots were randomly selected on 1:24,000 color infrared aerial photographs using a grid system with each cell being the size of a pixel. These plots were plotted on $1: 24,000$ scale topographic maps and their vegetation types verified through field observation. Normally, evaluation samples are selected from the Landsat classification map to obtain a completely random sample (Todd et al. 1980). In this study random samples were not used because of the variable nature of range vegetation (making it difficult to locate homogeneous evaluation plots). Ecotones were not sampled since they constitute a source of noiseinduced error (Daus 1975) where boundary Landsat pixels will include reflectance information from both plant communities.

Within each evaluation plot at least $13 \times 3$ pixel cluster sample was located so accuracy could be assessed. Minimum sample size required for each class (Table 1) was determined using the formula (Todd et al. 1980):

$$
n(i)=\frac{N(i) p(i) q(i)}{\left(N(i)\left(E^{2} / t^{2}\right)\right)+p(i) q(i)}
$$

where: $n(i)$ is the number of clusters needed (sample size)

$N(i)$ is the total size of class i divided by 9

$p(i)$ is the estimated accuracy of class $i$

$E$ is the allowable error (0.10)

$t$ is the Student's $t$ statistic at the allowable error and $q(i)$ is $L-p(i)$

The initial estimated accuracies of the different classes ( $p(i))$ were determined by preliminary field checking of easily accessible field plots and calculating the percent correct.

Accuracy was calculated in the form of percent correct in class $i$ and an average classification accuracy calculated from these values (Table 2). Confidence intervals were calculated using the standard Student's t formula (Table 3). The standard error of the estimate of p(i) (S.E.(p(i)) was used to calculate confidence intervals using the formula for an even number of sample elements within cluster samples (Cochran 1963);

$$
\text { S.E. }(p(i))=\sqrt{\frac{(p(j))-p(i)^{2}}{n(n-1)}}
$$

where: S.E. (p(i)) is the standard error of the estimate p(i), $p(U)$ is the percent correct in the jth cluster in class $i$, $p(i)$ is the percent correct for class $i$, and $n$ is the number of clusters in class $i$.

\section{Results and Discussion}

The final Landsat classification resulted in 14 spectral classes representing 8 range plant communities (Table 4). Spectral signatures for the 14 spectral classes are very similar (Fig. 1).

Table 2. Vegetation classification accuracy.

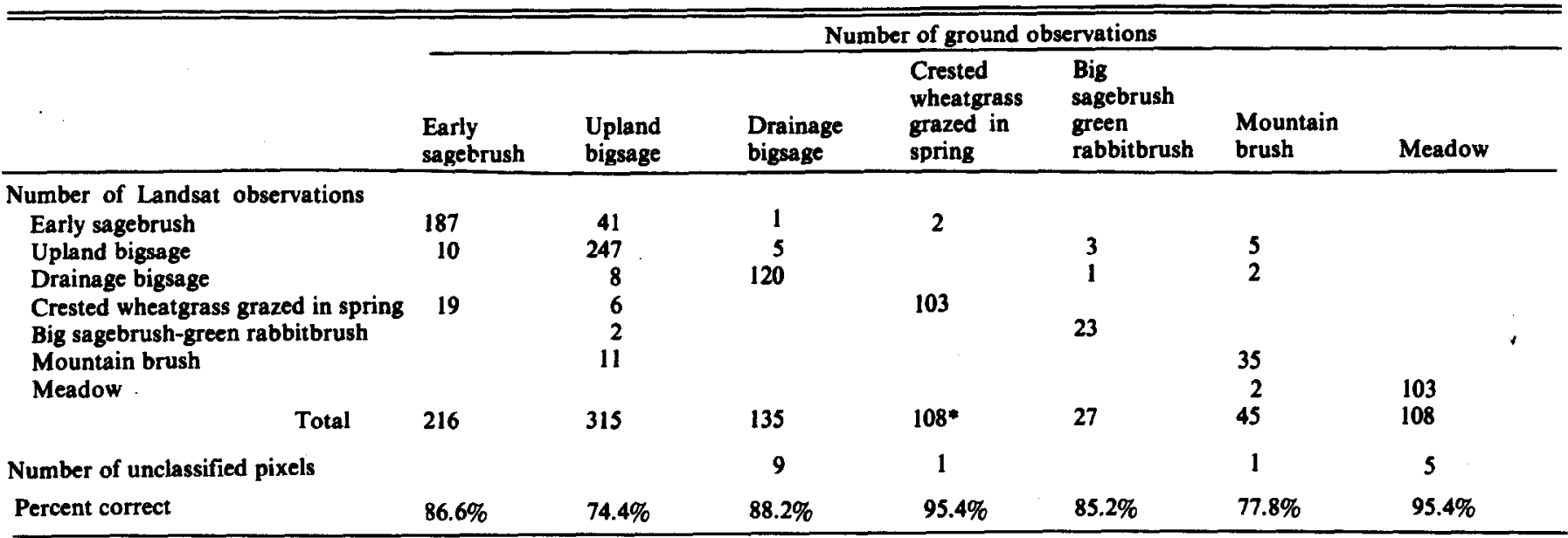

'Two pixels fell into the crested wheatgrass grazed in the fall class, which is not represented in this table since the entire class was sampled. 


\begin{tabular}{|c|c|c|}
\hline Vegetation class & $\begin{array}{c}\text { Standard error } \\
\text { of the estimate } \\
(\%)\end{array}$ & $\begin{array}{l}\text { Percent correct } \\
\& \text { confidence } \\
\text { interval at } \\
.05 \text { level }\end{array}$ \\
\hline $\begin{array}{l}\text { Early sagebrush } \\
\text { Upland big sagebrush } \\
\text { Drainage big sagebrush } \\
\text { Crested wheatgrass grazed in } \\
\text { spring }\end{array}$ & $\begin{array}{l}2.67 \\
4.22 \\
2.17 \\
2.54\end{array}$ & $\begin{array}{l}86.6 \% \pm 5.51 \\
78.4 \% \pm 8.57 \\
88.2 \% \pm 4.62 \\
95.4 \% \pm 5.53\end{array}$ \\
\hline $\begin{array}{l}\text {-Big sagebrush- } \\
\text { green rabbitbrush }\end{array}$ & & $85.2 \%$ \\
\hline $\begin{array}{l}\text { Mountain brush } \\
\text { Meadow } \\
\text { Crested wheatgrass grazed in fall }\end{array}$ & $\begin{array}{c}7.87 \\
2.54 \\
\text { Entire class was } \\
\text { sampled }\end{array}$ & $\begin{array}{l}77.8 \% \pm 20.23 \\
95.4 \% \pm 5.75 \\
83 \%\end{array}$ \\
\hline Mean accuracy of all sample plots & & $86.4 \%$ \\
\hline
\end{tabular}

-Inadequate sample for calculation of statistics.

The sagebrush classes have progressively higher means across the 4 bands as canopy cover decreases from class to class (Fig. 2). The meadow classes have a characteristic spectral signature for dense green vegetation. The grass classes (Grass $1,2,3,4$ ) have a characteristic green shift in band 6 with Grass 4 being highest in band 6 as expected since it is not grazed until fall and it is on the more moist site, giving it the highest green biomass (Fig. 3). Grass 3 is not grazed until fall either, but has considerable invasion of sagebrush, causing it to fall between Grasses 1 and 2 in band 6 . Grasses 1 and 2 are grazed in the spring.

The percentage correctly classified ranged from a high of $95.4 \%$ for the sample plots in the crested wheatgrass seedings grazed in the spring and for the meadow class, to a low of $77.7 \%$ for the sample plots in the mountain brush vegetation (Table 2 ). The overall mean classification accuracy for all sample plots was $86.4 \%$ (Table 3 ).

Most of the 14 spectral classes were identified by careful photo interpretation. However, classes such as Bigsage 1 and 2 and Grass 3 and 4, while different on the ground, could only be separated using the computer and spectral space as defined by the Landsat digital data. They were not readily identified on the aerial photographs.

The big sagebrush types were separated into 3 different big sagebrush spectral classes (Bigsage 1, 2, and 3). Bigsages 1 and 2 were combined to form the "upland bigsage" range type because they are extremely difficult to differentiate in the field. Differences among the big sagebrush classes were related to canopy cover and

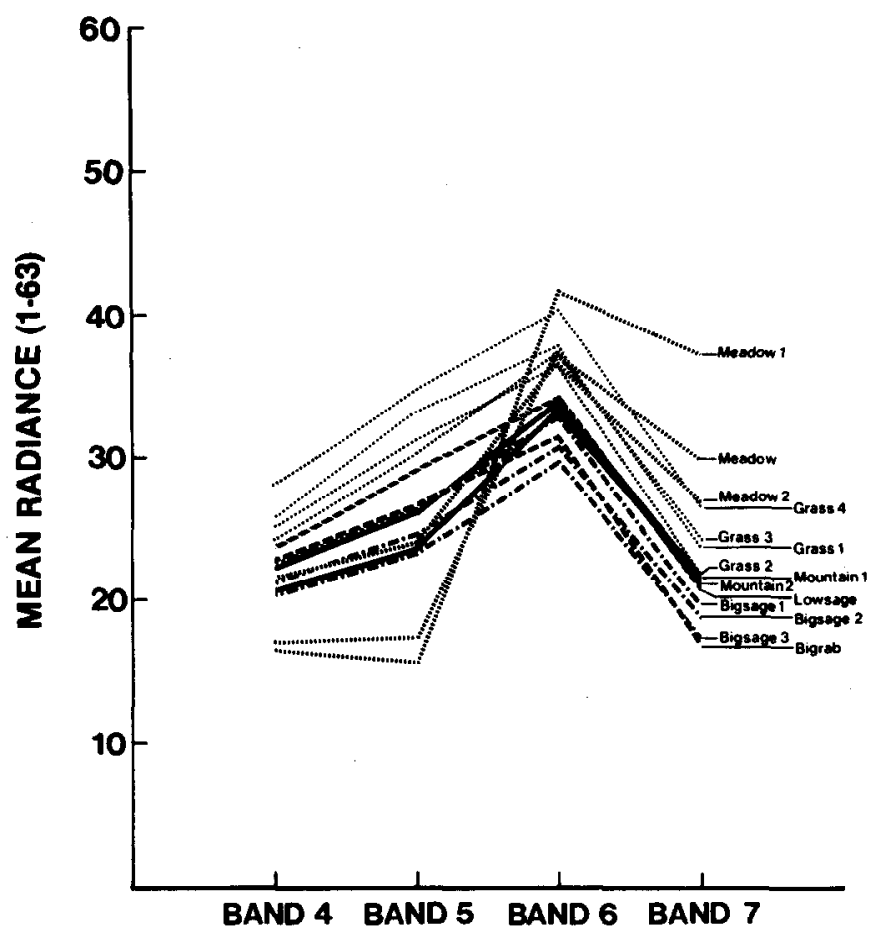

Fic. 1. Mean spectral radiance for each statistical class.

plant vigor. Bigsage 3 was found exclusively in the drainage bottoms where it has the highest canopy cover and the greatest overall vegetation vigor. Bigsage 2 (medium density) was found either in conjunction with Bigsage 3 along drainage bottoms or in smaller drainages at the base of the mountain range where soils are deep and relatively moist. Bigsage 1 has the lowest canopy cover and is found with greater frequency on shallower soils as one moves eastward from the mountain range.

These 3 big sagebrush classes are generally related to 3 subspecies of big sagebrush found in the area. Bigsage 3 (drainages) is dominated by big sagebrush, Bigsage 2 (intermediate big sagebrush sites) by mountain big sagebrush, and Bigsage 1 (poorest big sagebrush sites) by Wyoming big sagebrush.

Only one spectral class representing the early sagebrush type could be identified. Early sagebrush is relatively homogeneous and consistent on clay hardpan soils of the lower parts of the study area. Early sagebrush areas are referred to as lowsage in the tables and Figure 2.

Table 4. Summary of ctatiatical and resource clasaes for the Saval study area.

\begin{tabular}{|c|c|c|c|c|}
\hline Statistical class & Resource class & Pixels & Hectares & Percent of total area \\
\hline Lowsage & Early sagebrush & 9077 & 4099 & $26.3 \%$ \\
\hline $\begin{array}{l}\text { Bigsage } 1 \\
\text { Bigsage } 2\end{array}$ & $\begin{array}{l}\text { Upland big sagebrush } \\
\text { Upland big sagebrush }\end{array}$ & 10712 & 4837 & $31.0 \%$ \\
\hline Bigsage 3 & Drainage big sagebrush & 1250 & 564 & $3.6 \%$ \\
\hline $\begin{array}{ll}\text { Grass } 1 \\
\text { Grass } 2\end{array}$ & $\begin{array}{l}\text { Crested wheatgrass } \\
\text { Grazed in the spring }\end{array}$ & 5878 & 2654 & $17.0 \%$ \\
\hline $\begin{array}{ll}\text { Grass } & 3 \\
\text { Grass } & 4\end{array}$ & $\begin{array}{l}\text { Crested wheatgrass } \\
\text { grazed in the fall }\end{array}$ & 1174 & 530 & $3.4 \%$ \\
\hline $\begin{array}{l}\text { Meadow } \\
\text { Meadow } 1 \\
\text { Meadow } 2\end{array}$ & Meadow & 1901 & 860 & $5.5 \%$ \\
\hline $\begin{array}{l}\text { Mountain } 1 \\
\text { Mountain } 2\end{array}$ & Mountain brush & 2423 & 1094 & $7.0 \%$ \\
\hline Bigrab & Big sagebrush-green rabbitbrush & 1076 & 486 & $3.1 \%$ \\
\hline Unclassified & & 1009 & 496 & $3.2 \%$ \\
\hline Total & & 34500 & 15619 & $100.00 \%$ \\
\hline
\end{tabular}




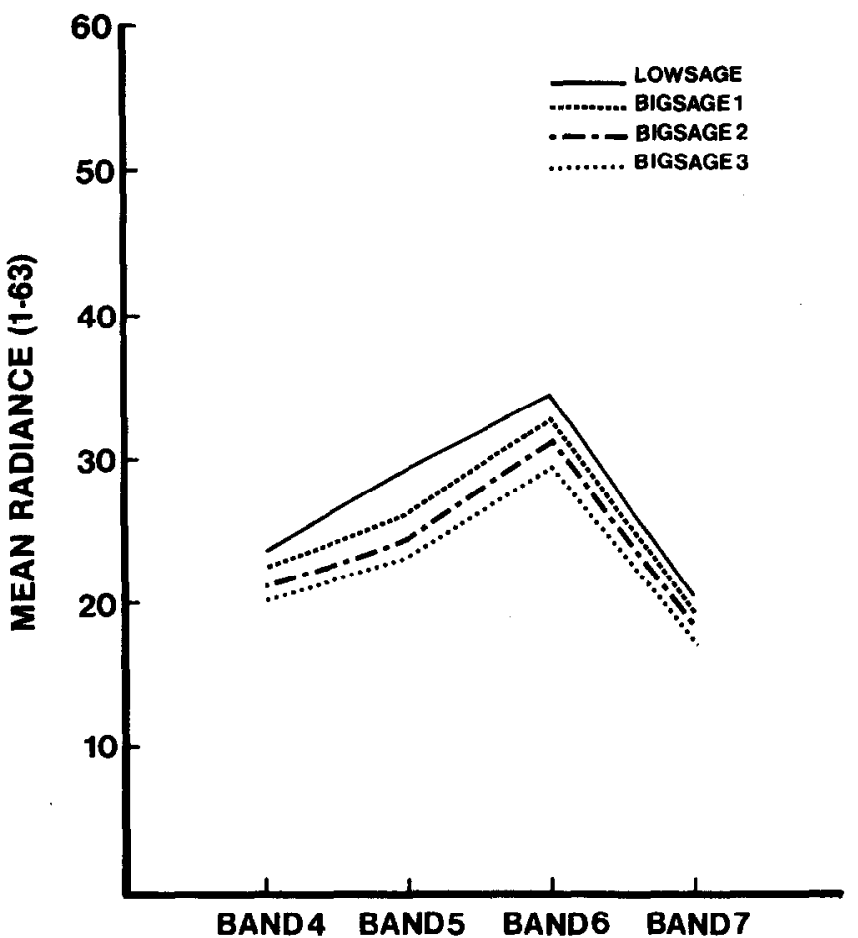

Fig. 2. Mean spectral radiance for each sagebrush class.

The crested wheatgrass seedings were divided into 4 different spectral classes. Grasses 1 and 2 were grazed heavily in the spring and have considerable bare soil. Grass 3 is confined mostly to one pasture that was grazed only in the fall. It was more vigorous than Grass 1 or 2 . Grass 4 , also grazed in the fall, was even more vigorous than Grass 3, because it was located in a moist bottomland close to a drainage. The 3 meadow spectral classes were grouped together because meadow classification was not the emphasis of the study.

At the base of the mountain range there were 2 mountain brush classes that were also combined to form a single class dominated by a variable mixture of big sagebrush, mountain mahogany (Cercocarpus ledifolius), and bitterbrush (Purshia tridentata). A final range type identified was a mixture of big sagebrush and green rabbitbrush. It is composed of nearly an even mix of big sagebrush and green rabbitbrush (Chrysothamnus viscidiflorus) and is usually found in the lower parts of major drainages.

Some pixels remained unclassified (Table 2). These pixels were either ecotones or areas not large enough to form their own statistical classes such as corrals or small stock watering ponds. Few software packages depict unclassified pixels. However, they are valuable for quickly locating and evaluating areas that do not represent any class and for decreasing misclassification. Because of vegetation heterogeneity, no given range should be classified without some unclassified pixels. In this classification 1,009 out of 34,500 or $2.9 \%$ of the pixels remain unclassified, a reasonable number for an allotment of this size. This characteristic of the analysis can be extremely valuable in identifying resource classes that may have been overlooked.

The early sagebrush vegetation presented 2 major classification problems. First, a large number (41) of "upland bigsage" pixels (Bigsage 1) were included in the early sagebrush class. Field investigation revealed the areas of upland big sagebrush tend to be confused with early sagebrush since they had low canopy cover, a high percentage of bare soil, and recently had received heavy grazing. Second, some early sagebrush (19) pixels were placed in the grass category. These spots were difficult to locate precisely in the field because they are so widely scattered. This classification problem appears on areas where early sagebrush is very sparse and where cheatgrass (Bromus tectorum) and bare soil are common.

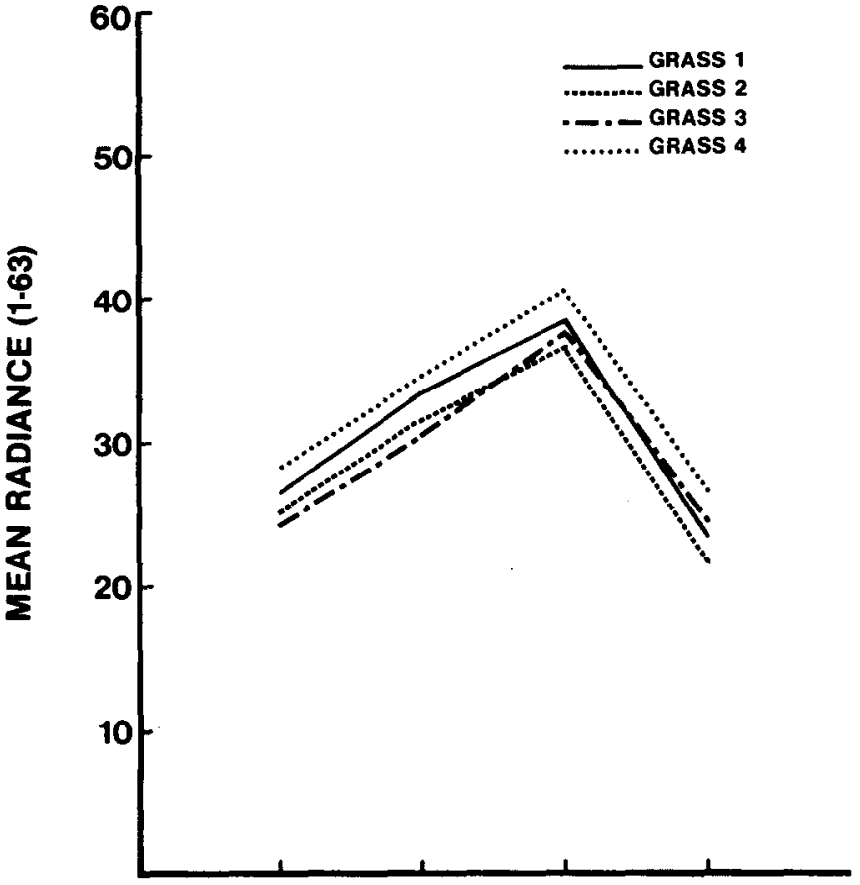

BAND 4 BAND 5 BAND 6 BAND 7

Fig. 3. Mean spectral radiance for each grass class.

Areas of sparse early sagebrush produce a spectral signature similar to that of grazed crested wheatgrass (Grass 1 and 2). Also, this misclassification may be caused by a high density of ant mounds 1.5 to $2 \mathrm{~m}$ in diameter. A large number of mounds and bare soil in early sagebrush stands produces a signature similar to grazed crested wheatgrass.

Mountain brush and upland big sagebrush communities were confused (11 pixels). Mountain brush types occur in patches throughout the upland big sagebrush with no definite transition zone. Field interpretation is difficult and is likely the cause of some classification errors.

Neither the mountain brush or big sagebrush-green rabbitbrush classes were adequately sampled (Table 1). Both plant communities are widely scattered and were often represented by 1 or a very small group of pixels. Sampling was thus extremely difficult and obtaining an adequate sample was impossible. Percentage correct results for these 2 classes may be misleading. Their scattered distribution made it impossible to conclude whether misclassification errors were due mostly to the scattered and spotty nature of the stands or whether they were not spectrally distinct.

Using the PIXSYS software with Landsat digital data and guided clustering techniques, 3 different canopy cover classes of big sagebrush and 2 different sagebrush communities, early sagebrush and big sagebrush, were separated. On crested wheatgrass seedings, those grazed in the spring are readily separable from those grazed in the fall. Crested wheatgrass grazed in the spring was not separable from cheatgrass-invaded areas in early sagebrush vegetation.

The spectral differences among range plant communities as derived from Landsat classifications are often very small. Differences between spectral classes that represent these communities tend to approach the noise level of the Landsat data. Because of the lack of relatively large homogeneous evaluation sites, it was impossible to conclude whether mountain brush and big sagebrush-green rabbitbrush were always distinguishable from other sagebrush communities at the study site.

A difficult problem common to this and most Landsat studies is the requirement for adequate ground data. Other techniques for separating vegetation signatures from bare ground signatures such as band ratioing (Tucker 1977) deserve investigation on desert 
shrublands.

Landsat digitized classification and mapping has potential for use in rangeland vegetation inventory. Studies such as this, Maxwell's (1976), and Bonner and Morgart's (1980) show that Landsat is a presently available data source that can be used to collect at least general baseline data for range inventories. With continued research into the use of digital Landsat data for automated rangeland inventories, combined with digitized aerial photography and geographic information (elevation, slope, soils, etc.), range trend and productivity may eventually be monitored economically and on a regular basis.

\section{Literature Cited}

Bonner, William J., and John Morgart. 1980. Landsat: A Sampling Frame For Arid Land Inventories. Proceedings Arid Land Resource Inventories: Developing Cost-Efficient Methods. An International Workshop. Nov.-Dec. LaPax, Mexico. p. 230-239.

Cochran, W.T. 1963. Sampling techniques, 2nd edition. John Wiley and Sons Inc., N.Y.

Daus, S.J. 1975. Utilization of automated data analysis techniques for Landsat-based range resource evaluations. In: Spacecraft and aircraft remote sensing for integrated unit resource inventory and analysis in northeastern California and northeastern Nevada. R.N. Colwell (ed.) BLM Final Rep. No. 52500-CT4-208(N).

Everitt, J.H., A.J. Richardson, A.H. Gerberman, C.L. Wiegand, and M.A. Alaniz. 1979. Landsat-2 data for inventorying rangelands in south Texas. Proc. 1979 Machine Processing of Remotely Sensed Data Symposium. 132-141.

Everitt, J.H., A.J. Richardeon, and C.L. Wiegand. 1981. Inventory of semi-arid rangelands in South Texas with Landsat data. Proc. 1981 Machine Processing of Remotely Sensed Data Symp. Purdue Univ. p. 404-415.

Maxwell, E.L. 1976. A remote rangeland analysis system. J. Range Manage. 29:66-7.

Rohde, W.G. 1978. Digital image analysis techniques required for natural resource inventories. AFIPS Conference Proceedings. Vol. 47. USDI Geological Survey, EROS Data Center, Sioux Falls, S.D.

Todd, W.J., D.G. Gehring, J.F. Haman. 1980. Landsat wildland mapping accuracy. Photogrammetric Engineering and Remote Sensing 6:509-520.

Tucker, C.J.1977. Use of near infrared/red radiance ratios for estimating vegetation biomass and physiological status. NASA/GSFL preprint X-923-77-183.

Tueller, P.T., F.R. Honey, and I.J. Tapley. 1978. Landsat and photograhic remote sensing for arid land applications in Australia. Proc. 12th Intern. Symp. of Remote Sensing. Vol. 3. p. 2177-2191. 